\title{
The Influence of the Transformational Leadership of the Headmasters on the Professional Development of Preschool Teachers
}

\author{
Zuriani Hanim Zaini ${ }^{1}$, Mahaliza Mansor ${ }^{2}$ \\ Universiti Pendidikan Sultan Idris, Tanjong Malim, Perak, Malaysia
}

Corresponding author: Zuriani Hanim Zaini (e-mail: zurianihanim@gmail.com)

\begin{abstract}
The purpose of this research is to study the influence of the transformational leadership of the headmasters on the professional development of national preschool teachers in Perak state. The design of this study is quantitative descriptive using questionnaires as the instrument. The sample consists of 260 national preschool teachers from Perak, Malaysia. The research instrument is adapted from Leadership Practice Inventory (LPI) and Readiness, Planning, Training, Implementation and Maintenance (RPTIM) Model. The findings showed that the level of the transformational leadership of the headmasters and the level of preschool teachers' professional development are high. Pearson correlation analysis showed a significant positive relationship between these two variables. The regression analysis showed a high percentage of transformational leadership contributing to the preschool teachers' professional development. In conclusion, transformational leadership of the headmasters has evidently influenced the professional development of preschool teachers. It supports the views that transformational leadership is an ideal leadership style to be practiced by the school leaders.
\end{abstract}

Keywords: transformational leadership, teacher professional development, principal leadership, preschool teachers

\section{INTRODUCTION}

Leadership is one of the main factors in forming a good organization to ensure that a goal can be achieved. In detail, Northouse (2016) states that leadership is a process in which an individual can influence other individuals to achieve a set of goals together. The leadership style of the headmasters in school administration is an issue that needs to be addressed in the field of educational management. This is because an effective school that has the potential to excel needs to be led by a leader who can give a huge impact on the productivity of teachers and staff (Day \& Harris, 2013).

Next, in order to make changes in the school organization, the headmaster plays an important role in providing guidance and solutions to ensure improvement in the quality of students learning and the professional development of teachers. Ongoing professional training and development of teachers will impact various aspects not only in terms of teaching and 
learning but also teacher personality, skills, and management. This is aligned with the vision that has been set by the Ministry of Education Malaysia (MOE), which is to provide a worldclass education.

By the third wave of the implementation of Malaysia Education Development Plan 2013-2025, the Continuing Professional Development (CPD) approach focuses on selfinitiatives and does not depend on the MOE or schools alone. The Sustainable Professional Development Plan (SPDP) was introduced in 2014 to complement the professional development efforts of teachers and school leaders. This plan aims to improve the quality of teachers and school leaders in empowering the teaching profession, which is a factor for student success.

In addition, the challenges of the $21^{\text {st }}$ century of education require teachers to find new teaching approaches, strategies, and methods. In line with that, the Malaysian Teachers Standard documents have provided a guideline towards the professional competencies that teachers need to achieve. Also, training agencies and institutions that provide training to teachers need to ensure that teachers can achieve the required level of competency. The Malaysian Teachers Standard model has also served to assist teachers in reflecting on their own level of achievement and identifying the need for professional development that has not yet been mastered. The document also defined the CPD as a systematic training program that leads to increased professionalism, career development, and excellent service quality of teachers.

In early childhood education, the need for continuous professional development of teachers in this field is very critical. This is because early childhood education teachers need to be competent in various teaching methods according to the development of children. As every child is different, teachers need to adapt teaching methods according to the particular needs of each child. Previous studies revealed that teacher quality is the vital factor in preparing children's skills to go to school than other factors (Neuman \& Kamil, 2010). Interventions in teacher professional development delivered more intensively and extensively can have a better impact on teachers and students (Zaslow, Tout, Halle, Vick \& Lavelle, 2010). Teacher professional development programs need to be done continuously and periodically to ensure that teachers can master and implement new knowledge or skills into the way teachers teach. Teachers also need to be competent in innovation and professional learning to teach and learn with technological evolution (Uers, Volman \& Kral, 2018). 


\subsection{Problem statement}

The Sustainable Professional Development Plan (SPDP) was first introduced in 2014 to complement the professional development efforts of teachers and school leaders in Malaysia. This plan aims to improve the quality of teachers and school leaders in empowering the teaching profession, which is one of the factors for student success. However, based on the studies that have been done, some problems have been identified. Studies show that parents are more satisfied with the quality of teaching in private preschool than the national preschool in terms of their environment, facilities and equipment, and the quality of the teachers (Yin, 2018).

This situation illustrates that national preschool needs further improvement in various aspects to offer the besteducational services to children and gain parents' trust. Masnan (2014), in his study, also stated that if teachers do not have and master pedagogical knowledge in the context of preschool education, the teaching and learning process implemented will be formal and more focused on teachers, which is very contradictory to the goals of preschool education by the MOE that emphasizes children's freedom to explore and learn. Other than that, the MOE report in 2018 found that only $26.3 \%$ of teachers who passed the level of excellent achievement in the implementation of $21^{\text {st }}$ century education and another $73.7 \%$ gained a minimum achievement of"good". This situation is in line with the findings of a study conducted by Chee, Nor, Othman, and Rahman (2018) about content pedagogical technology knowledge on preschool teachers. The study shows that teachers have not yet mastered content knowledge. They also practiced a teacher-centered approach and did not integrate technology in teaching.

The post-mortem finding from the MOE 2018 annual report has also reported that school administrators and teachers need guidance in implementing the $21^{\text {st }}$ century education style effectively. Therefore, a survey study needs to be conducted to identify whether the professional development program that the teachers received meets the needs of teachers for the teaching and learning process. However, the effectiveness of professional development programs can be influenced by various factors. A study conducted by Clement and Vandanberghe (2001) showed that teachers' professional development requires individual commitment as well as a conducive working environment.

The process of improving school achievement requires leaders who can share power by discussing together as well as having a sincere desire to build trust with their followers. Even school leaders need to provide an environment that supports interaction and participation, interdependence, sharing views and beliefs, accepts all, and establishes a good relationship 
between all staff and teachers (Zepeda, 2008). Therefore, this study needs to be done to identify the gaps in research on the influence of the headmaster's transformational leadership on preschool teachers' professional development and obtain their valuation on the transformational leadership practices of the headmasters and professional development throughout their service.

\subsection{Effective transformational leadership}

Past studies on transformational leadership have shown that leaders who practice transformational leadership can produce more effective employees. According to Leithwood and Jantzi (1990), transformational leadership practiced by leaders of an educational institution has a strong positive impact on organizational conditions, including improving the quality of teachers. Haj and Jubran (2016) study showed that the level of transformational leadership of principals in the district of Galilee, Jordan is at a high level due to their education ministry which strived to provide development programs for administrators through workshops, courses, and training for principals. This study also showed that principals' transformational leadership has influenced and positively correlated with employee satisfaction.

Another study by Man, Don and Ismail (2016) on transformational leadership and the quality of generation $\mathrm{Y}$ teachers also proved that the higher transformational leadership practiced among leaders, the higher the quality level of teachers can be produced. This study also suggested that school leaders need to emphasize the importance of the transformational leadership style because it is one of the key elements to improve the quality of teachers today. Next, Musa, Yusof, Yunus, and Hamid (2014) proved that the level of transformational leadership between the government and private secondary schools is also high. This study also stated that transformational leadership in terms of being a role model has been the dimension practiced by both principals. This dimension is seen to provide a good stimulus for teachers to achieve the goals, visions and missions of the organization and develop talents, interests and abilities of the teachers.

The study by Man et al. (2016) also reported that there is a positive relationship between the dimensions of intellectual stimulation and individual consideration with the quality of "Y" generation teachers. The study by Mayan and Mansor (2016) also recorded the highest score value on the same dimensions which is intellectual stimulation and individual consideration. Overall, the studies on the level of transformational leadership of the school leaders on most past studies have shown at a high level, although there are some differences in terms of characteristics or dimensions of transformational leadership practiced by each school leader. 
This is because every leader has their own style to lead an organization, and a leader should influence the work culture and management of the organization (Ismail and Don, 2015).

The characteristics of transformational leadership, as mentioned in previous studies, have shown many similarities in terms of transformational leadership style which is the basis for the study by Mayan et al. (2016), Man et al. (2016), and Haj et al. (2016). These include the ideal influence, intellectual stimulation, individual judgement and inspiring motivation. All of these studies are based on Bass and Avolio's leadership theories. The leadership dimension in the Kouzes and Posner (2017) model also shows the characteristics of transformational leadership that are very similar to the leadership theory of Bass and Avolio (1994). This is because Kouzes and Posner's leadership models were detailed from the results of Bass's study.

After all, these studies proved that transformational leadership is a suitable leadership style that every leader should practice because it is proven to impact the commitment, motivation, attitude, skills, and job satisfaction in an organization. In accordance with the definition given by Bass (1985), transformational leadership prioritizes a good relationship between leaders and followers. Open communication and sharing of ideas as well as information with each other will produce followers who are fun, highly motivated and well committed to the tasks given.

\subsection{Effective professional development}

Past studies on teacher professional development have proven the importance of professional development to ensure that teachers can get better exposure to knowledge and skills, which will impact the organization's performance and the individual itself. A study conducted on teachers in high-performing schools by Ghani et al. (2016) showed that the level of effectiveness of professional development programs is high in both zones, namely the central and southern zones of Malaysia. Other studies conducted in high-performing and lowperforming schools also found that the level of effectiveness of the implementation of professional development programs in the schools involved is high and very satisfactory (Ghani \& Adnan, 2015). This can illustrate that teacher professional development programs can improve teachers' professional knowledge, skills, and attitude. Furthermore, a study conducted by Bautista, Ng, Munez, and Bull (2016) on preschool teachers in Singapore showed that teachers themselves want continuous professional development related to all the pillars of the curriculum which is in line with the current needs and interest of the teachers. 
Next, the findings by Din and Viniwatanakhun (2019) in Myanmar showed that teachers' perceptions on professional development did not have significant differences according to demographic factors in terms of gender, class grade, and teaching experience. Nevertheless, the findings of the study also prove that teachers give positive feedback and acknowledge the importance of professional development in their career development. Therefore, the study suggests that the headmaster plays an important role in providing resources to carry out professional development activities at the appropriate time and fulfill the needs of teachers to impact students' academic achievement positively.

Furthermore, studies on the concept of collaboration in the Professional Learning Community (PLC) according to the Islamic perspective show that collaboration is an effort to help in doing charity work. Therefore, the collaboration between every school community member is believed to improve the school performance and self-achievement. However, the development of teachers' professionalism in improving teachers' knowledge also requires a good leadership strategy so that changes in school performance can be improved and implemented as planned. In fact, the PLC's objective aims to create improvement in teachers' teaching methods through collaborative practices that should be practiced among peers and educators (Ghani et al., 2015).

In addition, teacher self-efficacy is one of the factors that can enhance the professional development of teachers. This is because self-efficacy, according to Bandura (1986), is a person's belief or confidence in doing an action to achieve something successfully. According to Tschannen-Moran and Hoy (2001), the teacher's self-efficacy is the teacher's confidence in their ability to teach and motivate students. The study by Maulod et al. (2016) stated that there is a significant relationship between the emotional intelligence of principals and teachers' selfefficacy, consisting of teaching strategy, classroom management, and student involvement. Teachers who have high self-efficacy will be more motivated to improve their knowledge and skill in teaching and educating students.

For that reason, the implementation of professional development of teachers requires collaboration between leaders and teachers as well as administrative staff to ensure the development program. It will be carried out to meet the needs of teachers in terms of training content, time and other aspects in detail to ensure that it will be a useful program to enhance teachers' self-efficacy in teaching and learning process, and to achieve the organization goals. 


\subsection{Principal leadership strategies in teacher's professional development}

Earley and Bubb (2004) stated that effective professional development of teachers that has a high value would never happen without being led, managed, and implemented. Almost all models of school improvement, effectiveness, and sustainability were with the presence of a strong leader (O’Sullivan \& West-Burnham, 2011). Tschannen-Moran and Gareis (2015) also proved that principal leadership can give direct and indirect impact to students' excellence and increase teachers' commitment as well as the quality of the school's success.

Studies conducted by Ibrahim and Amin (2014) also proved that principals' teaching leadership has a positive relationship and contributes to teachers' teaching significantly. The teaching leadership in this study include three aspects namely, defining school goals, managing curriculum and teaching and lastly, fostering a teaching and learning exposure. The finding of the study showed that all three aspects in teaching leadership contributed to teachers' teaching competencies in terms of teacher-student interaction, teaching strategies, and classroom management. Therefore, these findings have proven that school leaders need to play a role as individuals who can demonstrate exemplary behavior and show a positive attribute and commitment towards the organization.

In addition, the study of Chang et al. (2017) in Taipei, Taiwan, showed that the change in the leadership style of principals impacted the professional development of teachers in terms of their willingness to participate and the effectiveness of their participation. This study also showed that there is no significant relationship between the role of gender, teaching experience, and school scale size on teachers' perception toward their principal leadership. Another study conducted in Malaysia showed that the change in the leadership style of the principals has a positive impact on teachers' motivation (Abdullah \& Ismail, 2017). The finding of this study also clearly proves that the leadership style has indirectly built a work environment that can influence the attitudes, perceptions, and productivity of the teachers through the formation of task and organization identity.

Other than that, job satisfaction also affects the leadership style in an organization. The relationship between teachers and the principals is very important in ensuring that the educational goals can be achieved. The findings by Yan-Li and Hassan (2018) proved that leaders who give support to teachers can increase their job satisfaction and make teachers more committed to continuous learning and strive to increase self-productivity to ensure that the goals of school organization can be achieved. The teachers will be more eager to participate in 
professional development programs without feeling compelled or forced by the school management.

This situation is in line with the findings by Senol and Dagli (2017) which showed that teachers are very committed to participate in training and staff development to improve the quality of education which requires the role of principals as a mentor and advisor, as well as a collaborator between the school community and school to improve the school performance. Teachers need leaders who can provide adequate direction and guidance for them to achieve a goal. Therefore, school leaders need to be smart in implementing different leadership styles according to the suitability of certain situations, and the individual needs to ensure that employees feel comfortable with the existence of a leader (Northouse, 1971), which, in turn, can affect the teacher productivity and student achievement.

Hence, apart from the headmaster, the responsibility as a leader should be shared equally with all teachers. The professional development process will be more effective if all teachers also play a role and practice leadership in the group themselves. This is because when teachers collaborate in performing tasks, indirectly they are also practicing small-scale leadership to help other colleagues, building trust and collectively solving problems (Lieberman \& Friedrich, 2007). Therefore, the following research questions were developed for this study:

a. What is the level of transformational leadership of the headmasters?

b. What is the level of professional development of the preschool teachers?

c. Is there any significant relationship between the transformational leadership of the headmasters towards the professional development of the preschool teachers?

d. Is there an influence between the transformational leadership of the headmasters towards the professional development of the preschool teachers?

\section{METHOD}

This study is a quantitative study that uses methods with descriptive analysis, correlation, and regression. It aimed at finding the relationships and differences between the variables that exist. This research was conducted at the national preschools in Perak state to measure the level of transformational leadership of the headmasters that affected the preschool teachers' professional development. All the national preschool teachers in Perak state are the population selected to carry out this research because they meet the criteria that represent the national preschools in Malaysia. 


\subsection{Sample size and location}

The sample for this study was selected according to the sample size determination table of Krejcie and Morgan (1970). The total population is 808 preschool teachers in Perak state, so only 260 teachers were needed as a sample for this study. Other than that, the significant level at $\mathrm{p}=.05$ according to the table of Cohen et al. (2001) also needs to be considered in determining the sample size, which also showed that the sample size of 260 respondents needed for his study is appropriate for this population. Next, the type of data sampling used for this study is a simple random sampling method so that each unit of the population has an equal chance of being selected (Cresswell, 2014).

\subsection{Research instrument and procedures}

Questionnaires were used as the research instrument to collect data from the respondents. The instrument consisted of three sections. Section A consisted of respondents' demographics. Section B consisted of 22 questions measuring the transformational leadership behavior of the headmasters adopted from the Leadership Practice Inventory (LPI) by Kouzes and Posners (2013). The items comprising five dimensions of leadership practices that model the way, inspire a shared vision, challenge the process, enable others to act, and encourage the heart. Responses were measured using five points Likert's Scale ( 1 = very low, 2 = low, 3 = moderate, $4=$ high and $5=$ very high). While for section $\mathrm{C}$ consisted of 23 questions measuring the preschool professional development that is adapted from Readiness, Planning, Training, Implementation, and readiness (RPTIM) by Wood et al. (1981). Responses were also measured using five points Likert's Scale ( $1=$ strongly disagree, 2 = disagree, $3=$ not totally agree, $4=$ agree and 5 = strongly agree).

\subsection{Validity and reliability}

Two language experts helped with the translation of the items in the questionnaires while another five subject experts helped to validate and give opinions on the suitability of the items used coincides with the operational definition of the study as well as in terms of the language, content, and format. Reliability analysis using the internal consistency approach (Cronbach's Alpha coefficients) showed that the items in section B (transformational leadership practice $=$ .98 ) and section $C$ (teachers' professional development $=.96$ ) were satisfactorily able to measure each variable and proceeded with the data analysis for 260 set of data $(\mathrm{N}=260)$. 
Other than that, linearity tests were also performed through a scatter plot graph in multiple regression analysis tests where all independent variables referred to as predictors had to be linearly correlated with dependent variables that is also referred to as criterion where the data showed should be in straight line format. The scatter plot residuals for this study have shown that the independent variable which is the transformational leadership of headmaster and the dependent variable which is the professional development of preschool teachers are correlated linearly and meet the assumption of linearity.

\subsection{Data collection procedure}

The data collection procedure started from obtaining permission from the division of planning and research of the Ministry of Education, Malaysia to distribute the questionnaires to the national preschool teachers. The respondents were chosen by using a random sampling method. The questionnaire form was distributed directly to the teachers after school. In another way, researchers have also contacted the district education officers to get access to selected preschool teachers from each district to answer the survey online using the Google Form platform.

\subsection{Data analysis procedure}

The data were analyzed using descriptive and inferential statistical methods by SPSS 23.0 software to answer all the research questions. To determine the suitable types of statistics to analyze the collected data, the normality test has been done. The normality test (skewness and kurtosis) showed that the data were normally distributed so the parametric test can be used. The method of analysis used to answer the first and the second research questions is a descriptive analysis method using mean and standard deviation. Meanwhile, Pearson correlation and multiple regression analysis is used to answer the third and fourth research questions consecutively.

\section{RESULTS}

\subsection{Level of transformational leadership practices of the headmasters}

Cresswell (2012) states that the use of mean values is a widely used method to describe the response of all respondents to the items in an instrument. The mean score interpretation for this study was referred to Pallant (2011) as follows: 
Table 1. Mean score interpretation

\begin{tabular}{lc}
\hline Level & Mean score \\
\hline High & $3.67-5.00$ \\
Moderate & $2.34-3.66$ \\
Low & $1.00-2.33$ \\
\hline
\end{tabular}

The findings on the level of transformational leadership practices among the headmasters are shown in table 2.

Table 2. Level of transformational lea dership practices of the headmasters

\begin{tabular}{lccc}
\hline Dimension & Mean & Sd & Level \\
\hline Model the way & 4.12 & .81 & High \\
Inspire a shared vision & 4.06 & .79 & High \\
Challenge the process & 3.85 & .09 & High \\
Enable others to act & 3.93 & .87 & High \\
Encourage the heart & 3.92 & .83 & High \\
\hline Total & 3.96 & .77 & High \\
\hline
\end{tabular}

The analysis in table 2 showed that the level of transformational leadership practices among headmasters was high $(\mathrm{M}=3.96, \mathrm{Sd}=.77)$. This analysis also showed that the dimension of the model way was practiced at the highest level $(\mathrm{M}=4.12, \mathrm{Sd}=.81)$ compared to other dimensions. Meanwhile, inspiring a shared vision $(M=4.06, S d=.79)$, enabling others to act $(\mathrm{M}=3.93, \mathrm{Sd}=.87)$, encouraging the heart $(\mathrm{M}=3.93, \mathrm{Sd}=.83)$ and challenging the process $(\mathrm{M}=3.92, \mathrm{Sd}=.83)$ scored the last. This analysis proved that the headmasters have been practicing transformational leadership at a high level.

\subsection{The level of the preschool teachers' professional development}

The findings on the level of the preschool teachers' professional development are shown in table 3 .

Table 3. Levelof the preschool teachers' professional development

\begin{tabular}{lccc}
\hline Phase & Mean & Sd & Level \\
\hline Readiness & 4.16 & .62 & High \\
Planning & 4.04 & .67 & High \\
Training & 4.00 & .66 & High \\
Implementation & 3.94 & .68 & High \\
Maintenance & 3.97 & .68 & High \\
\hline Total & $\mathbf{4 . 0 0}$ & $\mathbf{. 6 2}$ & High \\
\hline
\end{tabular}

The analysis in table 3 showed that the preschool teachers' level of professional development was high $(\mathrm{M}=4.00, \mathrm{Sd}=.62)$. This finding also showed that the readiness phase is the highest $(M=4.16, S d=.62)$. Meanwhile planning $(M=4.04, S d=.67)$, training $(M=4.00$, $\mathrm{Sd}=.66)$, maintenance $(\mathrm{M}=3.97, \mathrm{Sd}=.68)$ and implementation phase $(\mathrm{M}=3.94, \mathrm{Sd}=.68)$ scored 
the last. Thus, this analysis showed that preschool teachers' level of professional development practices is also high.

\subsection{Relationship between transformational leadership of the headmasters towards the professional development of the preschool teachers}

The findings on the relationship between transformational leadership of the headmasters towards the professional development of the preschool teachers are shown in table 4.

Table 4. Relationship between transformational lea dership and professional development

\begin{tabular}{lccc}
\hline & N & Pearson's correlation $(\boldsymbol{r})$ & Sig. \\
\hline $\begin{array}{l}\text { Transformational leadership } \\
\text { Professional development }\end{array}$ & 260 & .68 & .00 \\
** correlation is significantat 0.001 level (2-tailed) & & &
\end{tabular}

Pearson's correlation analysis in table 4 showed that there was a positive and strong relationship between the transformational leadership of the headmasters and the professional development of preschool teachers $(r=.68)$ at a significant level of $\mathrm{p}<.001$.

\subsection{The influence between transformational leadership of the headmasters tow ards the professional development of the preschool teachers}

Standard multiple regression analysis procedures were used to prove the influence of transformational leadership towards professional development. All the predictor variables (independent variables) were analyzed simultaneously in this regression equation to find out the total variance of the dependent variables that can be explained by predictor variables. The findings on the influence between transformational leadership of the headmasters towards the professional development of the preschool teachers are shown in these tables.

Table 5. Model summary

\begin{tabular}{lccccc}
\hline Model & $\boldsymbol{R}$ & $\boldsymbol{R}$ Square & Adjusted $\boldsymbol{R}$ Square & Contribution \% & $\boldsymbol{S P}$ \\
\hline 1 & $.69^{\mathrm{a}}$ & .47 & .46 & 47 & .458 \\
\hline a.dependent variable:professional development & & &
\end{tabular}

Table 6. ANOVA statistic

\begin{tabular}{llccccc}
\hline Model & & $\begin{array}{c}\text { Sum of } \\
\text { Squares }\end{array}$ & df & $\begin{array}{c}\text { Mean } \\
\text { Square }\end{array}$ & F & Sig. \\
\hline 1 & Regression & 47.55 & 5 & 9.51 & 45.33 & $.000^{\mathrm{b}}$ \\
& Residual & 53.29 & 254 & .21 & & \\
& Total & 100.84 & 259 & & & \\
\cline { 2 - 6 }
\end{tabular}

b. independent variable: transformational leadership 
Table 7. regression output coefficient

\begin{tabular}{llccc}
\hline & $\boldsymbol{B}$ & $\boldsymbol{B e t a}$ & $\boldsymbol{t}$ & Sig. \\
\hline (Constant) & 1.84 & & 11.61 & .000 \\
Model the way & -.02 & -.03 & -.26 & .796 \\
Inspire a shared vision & .12 & .15 & 1.19 & .235 \\
Challenge the process & .20 & .25 & 2.83 & .005 \\
Enables other to act & .13 & .18 & 1.30 & .194 \\
Encourage the heart & .13 & .18 & 1.56 & .119 \\
\hline
\end{tabular}

a. Dependent Variable: professional development

The regression analysis based on table 5 tells that the $\mathrm{R}$ square value to the professional development of the preschool teachers (dependent variable) that is associated with the transformational leadership of the headmasters is 47 percent $(.47 \times 100)$. Meanwhile, table 6 (ANOVA statistic) showed that this model is significant at $p<.05$. This means that the five dimensions in transformational leadership of the headmasters had contributed and influenced the professional development of the preschool teachers by 47 percent at a significant level $(\mathrm{p}<$ $.05)$.

These results also indicate a variant change in the transformational leadership of the headmasters towards the professional development of the preschool teachers at $[\mathrm{F}(5,254)=$ $45.33, \mathrm{p}<.005]$ when all the five dimensions of transformational leadership are combined in measuring the influence on the professional development of the preschool teachers. This also means that when the transformational leadership of the headmasters increases by 1 unit, then the professional development of preschool teachers will increase by .47 or 47 percent.

In fact, the findings of this study also proved that the transformational leadership of the headmasters gives a large level of contribution to the professional development of preschool teachers in this state. The regression equation that can be constructed based on this multiple regression analysis is:

$$
\mathrm{Y}=1.84+(-.02) \mathrm{X} 1+0.12 \mathrm{X} 2+0.20 \mathrm{X} 3+0.13 \mathrm{X} 4+0.13 \mathrm{X} 5+0.46
$$

Indication:

$\mathrm{Y}=$ preschool teacher's professional development

$\mathrm{X} 1=$ model the way

$\mathrm{X} 2=$ inspire a shared vision

$\mathrm{X} 3=$ challenge the process

$\mathrm{X} 4=$ enables other to act

$\mathrm{X} 5=$ encourage the heart

Constant $=1.84$ 


\section{DISCUSSION}

The survey result among the preschool teachers in this study proved that the headmasters have adopted transformational leadership practices in their administration. In another study by Daud et al. (2015) and Don et al. (2016) that used LPI as the instrument of their study also showed that both leaders in an effective school and in the northern zone national school have been practicing a high level of distributive leadership style. So, it is proven that the teachers highly regard the headmasters' role as a leader. The findings were also consistent with the study by Taylor, Psotka and Legre (2015), Haider, Nisar, Gill, and Ali (2017) and also Lee, Woo and Kim (2018) which showed that transformational leadership practices by leaders gave a significant impact on employees behaviour, job satisfaction and their motivation towards the organization.

These findings clearly showed that headmasters played an important role as a role model for preschool teachers by showing their values, attitudes and behaviours, which built trust and gave good examples to the teachers under their administration. Subsequently, teachers felt confident to commit to the headmasters' planning and achieve the education goals set by the school organization. This situation can also be attributed to the theory of social learning by Albert Bandura who believes in individual learning that occurs by imitating the behaviour of the people in their own environment, and indirectly, it will be a cognitive process as well as the individual's ability to make decisions.

Furthermore, the evaluation of the preschool teachers towards their professional development was also high. This proved that preschool teachers have a positive attitude towards the professional development program that they have undergone. B orko (2004) stated that professional development of teachers provides opportunities for teachers to impart knowledge, improve teaching skills and reflect on their teaching method. In fact, most teachers are also aware of the benefits of their involvement in professional development programs that can help them to expand their profession to a greater level (Opfer \& Pedder, 2011). In line with that, the MOE goal aims that the practice of continuous professionalism will continue to increase to $60 \%$ by 2025 with the efforts of strengthening the implementation of the Professional Learning Community (PLC) by giving autonomy to teachers and school leaders to undertake professional development through their self-initiative.

Subsequently, the findings obtained in this study suggested that there is a significant and strong positive relationship between transformational leadership practiced by the 
headmasters towards the preschool teachers' professional development, which means that if the transformational leadership practices increase, the preschool teachers' professional development will also increase. A previous study by Stevenson et al. (2016) showed that teachers professional development happened with monitoring from the headmaster. This study reported that the headmaster has given the teachers freedom to choose their way of learning in which specific programs provided in advance before the teachers could carry out more self professional learning. Therefore, headmasters need to express support, build trust and relationships among teachers to contribute ideas, knowledge, and skills with each other in forming collaborations for improving school performance and teachers' self-efficacy at the same time.

Besides, the regression analysis showed that the five dimensions in transformational leadership practiced by the headmaster had contributed significantly to the professional development of the preschool teachers. This analysis also proved that transformational leadership occurs holistically. Transformational leadership is an ongoing journey or a process by leaders in achieving outstanding achievement in an organization. To ensure such success, school leaders must also show their desire to change and affect the teachers' motivation and commitment. They will continue to improve their teaching skills to increase the success of the students' development. In line with this opinion, Chang et al. (2017) also found that the leaders who are willing to make changes will increase teachers' willingness to participate in professional development, which will help teachers to improve their teaching knowledge and skills. Apart from that, the findings of this study can also be related with Vygotsky's sociocultural theory which emphasizes on the importance of an active role of a person to construct knowledge through their social environment (Vygotsky, 1978).

Hence, the results of this study have given a clear perspective on the importance of leadership on teacher's behavior. This is because leaders are very influential on the motivation and commitment of teachers in teaching and preschool management as an effort in shaping students' development and creating a good organization. Therefore, the transformational leadership style is seen as very suitable to be practiced by leaders in educational organizations who are constantly faced with the evolution of education from time to time.

\section{CONCLUSION}

The findings of this study have proven that the practice of transformational leadership of headmasters has a significant influence on the professional development of preschool teachers. 
The high level of transformational leadership practiced by the headmasters is able to influence the effectiveness of teachers' professional development holistically, which in turn can also impact the management and administration practices in schools. In fact, the headmasters are one of the major key roles in mobilizing the education system in schools so that preschool teachers will get enough information and encouragement to perform the tasks of teaching and managing students. Ongoing cooperation while creating a good emotional relationship between school leaders and teachers will impact school performance and knowledge development as well as the quality of preschool education in our country.

In addition, this study has strengthened the importance of the combination of transformational leadership theory and professional development in creating a positive school practice and culture as well as in ensuring the preschool organization goals can be made. Therefore, further research methods can be diversified through observational or interview methods to answer the research questions comprehensively. Various research methods in the future need to be done to improve the literature studies on transformational leadership and professional development in the education field. Other than that, Structural Equation Modelling (SEM) methods can be used to determine the validity and test the relationship between variables. This SEM method can also be used to determine and validate the study of regression models, making them more accurate and in-depth.

\section{Acknowledgement}

This research received no specific funding from any agency in the public, commercial, or nonprofit sectors.

\section{REFERENCES}

Abdullah A.S, \& Ismail S.N. (2017). The relationship of headmasters' shared leadership and teachers' motivation in primary schools. International Journal of Education, Psychology and Counselling. 2(6). pp.202-213.

Bandura, A. (1986). The explanatory and predictive scope of self-efficacy theory. Journal of social and clinical psychology, 4(3), 359-373.

Bass, B. M. (1985). Leadership and performance beyond expectations.

Bass, B. M., \& Avolio, B. J. (Eds.). (1994). Improving organizational effectiveness through transformational leadership. Sage.

Bautista, A., Ng, S. C., Múñez, D., \& Bull, R. (2016). Learning areas for holistic education: Kindergarten teachers' curriculum priorities, professional development needs, and beliefs. International Journal of Child Care and Education Policy, 10(1), 8.

Borko, H. (2004). Professional Development and teacher learning: Mapping the terrain. Educational Researcher, 33(8), 3-15. 
Chang, D. F., Chen, S. N., \& Chou, W. C. (2017). Investigating the major effect of principal's change leadership on school teachers' professional development. IAFOR Journal of Education, 5(3), 139-154.

Chee, J., Nor, M. M., Othman, A. J., \& Rahman, M. N. A. (2018). Issues of content knowledge, pedagogy and technology among preschool teachers. JuKu: Jurnal Kurikulum \& Pengajaran Asia Pasifik, 6(1), 7-21.

Clement, M., \& Vandenberghe, R. (2001). How school leaders can promote teachers' professional development. An account from the field. School Leadership \& Management, 21(1), 43-57

Cohen, J. (2001). Statistical power analysis for the behavioral sciences. Routledge.

Cresswell, J. W. (2012). Educational research planning, conducting and evaluating quantitative and qualitative research $\left(4^{\text {th }} \mathrm{ed}\right)$ - Boston, USA: Pearson Education Inc.

Cresswell, J. W. (2014). Research design: qualitative, quantitative, and mixed methods approaches-John W. Creswell.

Daud, Y., Yusoff, Z. J. M., Khalid, R., Don, Y., Omar-Fauzee, M. S., Raman, A., \& Hussin, F. (2015). Distributive leadership among leaders in effective schools. Journal ofTeaching and Education, 4(03), 423-433.

Day, C., \& Harris, A. (2002). Teacherleadership, reflective practice, and school improvement. In Second International Handbook of Educational Leadership and Administration (pp. 957-977). Springer: Dordrecht.

Din, B., \& Vinitwatanakhun, A. (2019). A comparative study of teachers' perceptions towards professional development according to their demographics at No. 1, Basic Education High School, Bhamaw, Kachin State, Myanmar. Basic Education High School, Bhamaw, Kachin State, Myanmar (March 13, 2019).

Don, Y., Raman, A., Hussin, F., \& Kasim, K. (2016). The role of teacher leadership and extracurricular activities in the construction of the soft skills of secondary school students in Malaysia. International Journal of Academic Research and Development, 1(3), 89-95.

Earley, P., \& Bubb, S. (2004). Leading and managing continuing professional development: developing people, developing schools. Sage.

Ghani, M. F. A., \& Adnan, A. K. (2015). Malaysian teacher professionalism development model analysis study in high performing school and low performing schools. JuPiDi: Jurnal Kepimpinan Pendidikan, 2(2), 1-16.

Ghani, M. F. A., Adnan, A. K., Hussin, Z., Radzi, N. M., Ahmad, A. M., \& Elham, F. (2017). Professional development program for high -performing school teachers. JuPiDi: Jurnal Kepimpinan Pendidikan, 3(3), 76-103.

Haider, S., Nisar, Q. A. L. I., Gill, S. S., \& Ali, Z. (2017). Ensuring citizenship culture: A longitudinal study of transformational leadership. Journal of Business and Social Development 5(2), 25-35. Penerbit Universiti Malaysia Terengganu.

Haj, S. J., \& Jubran, A. M. (2016). The extent of principals' application of the transformational leadership and its relationship to the level of job satisfaction among teachers of Galilee Region. Journal of Education and Practice,7(11), 114-119 Retrieved from: https://files.eric.ed.gov/fulltext/EJ1099552.pdf

Ibrahim, M. Y., \& Amin, A. (2017).Principal teaching leadership model and teacher teaching competencies. JuKu: Jurnal Kurikulum \& Pengajaran Asia Pasifik, 2(1), 11-25.

Ismail, S. N. B., \& Don, Y. B. (2017). Comprehensive quality management practices (TQM) and the relationship to principal leadership style. JuPiDi: Jurnal Kepimpinan Pendidikan, 2(1), 1-13.

Kouzes, J. M., \& Posner, B. Z. (2013). Lpi®: Leadership Practices Inventory®. 
Kouzes, J. M., \& Posner, B.Z. (2017). The leadership challenge workbook revised. John Wiley $\&$ Sons.

Krejcie, R. V., \& Morgan, D. W. (1970). Determining Sample size for research activities. Educational and psychological measurement, 30(3), 607-610.

Lee, Y. H., Woo, B., \& Kim, Y. (2018). Transformational leadership and organizational citizenship behavior: Mediating role of affective commitment. International Journal of Sports Science and Coaching, 13(3), 373-382

Leithwood, K., \& Jantzi, D. (1990). Transformational leadership: How principals can help reform school cultures. School Effectiveness and School Improvement, 1(4), 249-280.

Man, J., Don, Y., \& Ismail, S. N. (2017). transformational; leadership and quality of generation 'Y' teachers. JuPiDi: Jurnal Kepimpinan Pendidikan, 3(1), 29-42.

Masnan, A. H. (2014). The pedagogical practice of beginner preschool teachers (Doctoral dissertation, Universiti Sains Malaysia).

Maulod, S. A., Piaw, C. Y., Ahmad, H., Wei, L. M., \& Alias, S. (2017). Principal emotional intelligence and its relationship with secondary self-efficacy of secondary of school teachers. JuPiDi: Jurnal Kepimpinan Pendidikan, 3(3), 54-75.

Mayan, M. P., \& Mansor, M. (2016). Transformational leadership of headmasters towards the attitude and skill of secondary school discipline teachers in Gombak. International Conference on Accounting, Management and Economics (ICAME2016). Retrieved from: https://www.researchgate.net/publication/315829638

Musa, K., Yusof, H., Yunus, J. \& Hamid, S. A. (2014). Principal transformational leadership: A comparison between excellent public and private secondary schools. Management Research Journal, 3, 120-139.

Neuman, S. B., \& Kamil, M. L. (Eds.). (2010). Preparing teachers for the early childhood classroom: Proven models and key principles. Baltimore, MD: Paul H. Brookes.

Northouse, P. G. (2016). Leadership: Theory and practice. Sage publications.

O'Sullivan, H., \& West-Burnham, J. (Eds.). (2011). Leading and managing schools. SAGE.

Opfer, V. D., \& Pedder, D. (2011). Conceptualizing teacher professional learning. Review of Educational Research, 81(3), 376-407.

Pallant, J. (2011). Survival Manual. A step by step guide to data analysis using SPSS (4th ed.) Crows Nest, New South Wales, Australia: Allen \& Unwin

Senol, H., \& Dagli, G. (2017). Increasing service quality in education: views of principals and teachers. Eurasia Journal of Mathematics, Science and Technology Education, 13(8), 4857-4871

Stevenson, M., Hedberg, J. G., Sullivan, K. O., Howe, C., (2016). Professional development in education leading learning: The role of school leaders in supporting continuous professional development. Professional Development in Education

Taylor, T. Z., Psotka, J., \& Legree, P. (2015). Relationships among applications of tacit knowledge and transformational/transactional leader styles: An exploratory comparison of the MLQ and TKML. Leadership \& Organization Development Journal, 36(2), 120-136.

Tschannen-Moran, M., \& Gareis, C. R. (2015). Faculty trust in the principal: An essential ingredient in high-performing schools. Journal of Educational Administration, 53(1), 66-92.

Uerz, D., Volman, M., \& Kral, M. (2018). Teacher educators' competences in fostering student teachers' proficiency in teaching and learning with technology: An overview of relevant research literature. Teaching and Teacher Education, 70, 12-23.

Vygotsky, L. (1978). Mind in society: the development of higher psychological processes. Cambridge: Harvard University Press. 
Yan-Li, S., \& Hassan, D. (2018). Leadership behaviour on job satisfaction in malaysian national secondary schools: motivation and hygiene satisfaction. MOJEM: Malaysian Online Journal of Educational Management, 6(3), 48-67.

Yin, T. H. (2018). Tahap kepuasan ibu bapa terhadap kualiti pendidikan prasekolah di daerah Maran, Pahang. Jurnal Pendidikan Awal Kanak-kanak Kebangsaan, 7, 83-100.

Zaslow, M., Tout, K., Halle, T., Vick, J., \& Lavelle, B. (2010). Towards the identification of features of effective professional development for early childhood educators: a review of the literature. Report prepared for the US Department of Education.

Zepeda, S. J. (2013). Professional development: What works. Routledge. 